\title{
E D I T O R I A L
}

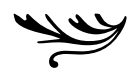

Charles Burney had high hopes for Naples. As he trekked ever southward in the summer of 1770, stopping along the way at Turin, Milan, Venice, Bologna, Florence and Rome, he imagined his approach to Naples as an ascent to a musical Parnassus: 'My visits to other places were in the way of business, for the performance of a task I had assigned myself; but I came hither animated by the hope of pleasure. And what lover of music could be in the place which had produced the two Scarlattis, Vinci, Leo, Pergolesi, Porpora, Farinelli, Jommelli, Piccinni, Traetta, Sacchini, and innumerable others of the first eminence among composers and performers, both vocal and instrumental, without the most sanguine expectations?'. The recent account of a similar pilgrimage by Jérôme de Lalande had whetted Burney's appetite for a city the Frenchman described as 'the principal source of Italian music, of great composers, and of excellent operas' (Voyage d'un François en Italie, 1769). Moreover, as he progressed down the peninsula he met musician after musician with ties to that Mecca of the south. And so he wrote of his arrival 'about five o'clock in the evening, on Tuesday, October 16': 'I entered this city, impressed with the highest ideas of the perfect state in which I should find practical music'. His reverie, however, was short-lived. Indeed, he quickly formed an aversion to flesh-andblood Neapolitan vocalists, instrumentalists, their performance practices, the audiences, even the gilding in the churches - in short, most of what he saw and heard.

Burney was deeply perplexed. Of composers in general he was convinced that 'those of Naples have long enjoyed the reputation of being the first contrapuntists, or composers, in Europe'. In the case of Jommelli in particular he praised 'this truly great composer, who is indisputably one of the first of his profession now alive in the universe; for were I to name the living composers of Italy for the stage, according to my idea of their merit, it would be in the following order: Jommelli, Galuppi, Piccinni, and Sacchini' (all but Galuppi trained in Naples). As a historian he knew that the conservatories were of tremendous importance. He used his personal interviews with Jommelli and Piccinni to press them for details of the conservatories' rules and organization. Guided by a certain Mr Oliver, an English student at the conservatory of San Onofrio, he made a personal visit to that institution to see how such famous musicians might be trained. Yet like a Virgil leading Dante down through successively deeper, more terrible levels of hell, so Mr Oliver led Burney through what seemed one horror after another: 'On the first flight of stairs was a trumpeter, screaming upon his instrument till he was ready to burst; on the second was a french-horn, bellowing in the same manner. In the common practising room there was a Dutch concert, consisting of seven or eight harpsichords, more than as many violins, and several voices, all performing different things, and in different keys'. It was an inferno 'of such jargon, and continued dissonance' that he doubted if anything fine could ever emerge from it. A second foray five days later only served to confirm his first impression: 'the noise and dissonance are beyond all conception'.

If a Neapolitan conservatory struck his senses more as Bedlam than Parnassus, more Inferno than Paradiso, intellectually he knew that the conservatory system had produced marvels. So after returning to England he drew up a 'Sketch of a Plan for a Publick Music-School' (1774), addressed to 'The Governors and Guardians of the Hospital for the Maintenance and Education of Exposed and Deserted Young Children'. In that plan he laid out rules and an organization openly modelled on the Neapolitan conservatories. Foundlings would be taken in and taught this useful trade, the church would be provided with free musicians for ever more attractive services, older students would teach younger ones, the very best would be hired out for professional engagements and all the proceeds would go toward support of the school. In spite of his advocacy for this 'Musical Conservatorio', which would have conveniently placed Burney as a well paid 'Principle Master', he seems never to have fully discerned what made the Neapolitan conservatories so successful. He was, to be sure, impressed by the application and 'constant perseverance' of their students: 'during the winter, the boys rise two hours before it is light, from which time they continue their exercise, an hour and a half at dinner excepted, till eight o'clock at night'. But he failed to recognize the intangible object of that application. 
The boys at the 'seven or eight harpsichords' in the same room at San Onofrio were probably pounding out partimenti. These lightly figured or unfigured basses intended for realization as complete keyboard works probably appeared to him, as they did to Joel Lester two centuries later (Compositional Theory in the Eighteenth Century (Cambridge, MA: Harvard University Press, 1992)), as mere objects for 'rote learning' set pieces to be played over and over until committed to memory. The cacophony at San Onofrio concealed from Burney a remarkable insight: those boys were initiates in a mental discipline for training the musical imagination. Partimenti helped to encode mental representations - schemata - of the stock phrases, cadences and sequences necessary for anyone expecting some day to 'speak' galant music in a courtly setting. Only a few of these schemata - famous basses like la romanesca and la folia - are still recognized today. But the conservatories taught dozens more, each appropriate to a given musical situation. The boys had to infer the proper sequence of schemata from the meagre clues of a partimento bass line. They then had to imagine upper parts, points of imitation, motivic echoes, the give-and-take of solo and tutti, strettos, canons - all the elements of their musical culture and craft. Learning to imagine and then to play hundreds of partimenti in all the current styles took a long time, contractually eight years for the typical seven- to ten-year-old matriculant. But the result was real fluency and the ability to fashion musical thought into multi-voice counterpoint. Even when Burney sat down with one of the masters of San Onofrio, Don Carlo Cotumacci, and was shown Cotumacci's own partimenti, Burney saw only 'two books of his own writing, in manuscript, one upon accompaniment, and one upon counterpoint'. The musical schemata that form the scaffolding for a huge number of galant musical phrases could, in a sense, be described as both 'accompaniment' and 'counterpoint'. That is, they store detailed knowledge about how a carefully scripted pas de deux of treble and bass could serve to support and organize a particular musical utterance. But Burney, even when shown these gems of the Neapolitan school by this student of the great Alessandro Scarlatti, failed to recognize what they were. Too much remained lost in translation.

Two centuries later I began my studies under the maestri Leonard B. Meyer, Eugene Narmour and Eugene Wolf. They taught at a school in Pennsylvania whose founder, Benjamin Franklin, had been praised by Burney for having invented the lightning rod. Meyer, officially the Benjamin Franklin Professor of Music, had just written 'Exploiting Limits: Creation, Archetypes and Style Change' (Daedalus 109/2 (1980), 177205). In it he discussed how a phrase-length musical gestalt underpinned different themes in works by Mozart, Beethoven and Berlioz. At the time I wondered if those correlations were truly representative or merely fortuitous. For me an electrifying moment came when I walked into the stacks of the Van Pelt Library, stopped at a more or less random location within the music section, pulled from the shelf what turned out to be a Bryan edition of one of Johann Vanhal's symphonies, opened it to a first-movement Allegro and saw to my chagrin the very thematic archetype described in Meyer's essay. While my single selection hardly qualified as a scientific sample, finding that theme helped spark my interest in pursuing the possibilities sketched by Meyer. I went on to explore and document the history of that schema in A Classic Turn of Phrase: Music and the Psychology of Convention (Philadelphia: University of Pennsylvania Press, 1988) before turning my attention to the whole repertory of eighteenth-century musical schemata.

Digging my way through mountains of eighteenth-century scores, I found ample evidence of a repertory of highly schematized musical behaviours. But I wondered how young composers of Burney's era, without the benefit of collected editions or microfilms, could have learned representative examplars of all these important patterns. Repeated exposure to common musical patterns might explain an adult's accumulated knowledge of musical schemata, but what about those boys in Naples? In 2002, quite by chance, I happened to be discussing a peculiarity of one such schema with my colleague Jesse Rosenberg. He mentioned that our topic had likewise been an issue for the partimento masters of Naples. 'Partimento?', I replied, not recognizing the word. He went to his office and fetched a copy of the partimenti that Paisiello had written for his Russian patroness the Grand Duchess Maria Feoderovna (St Petersburg, 1782). I opened its pages of mostly unfigured basses and began to hear the very same schemata that I had been studying. Apparently these partimenti were encapsulations of the core schemata of the galant style, almost in secret code. Through the drudgery of comparing slight variations in thousands of galant musical phrases I had built up, by dint of 
exposure and long contemplation, nearly the same mental representations taught intuitively through partimenti. I had taken the long way around, so to speak, but had arrived at nearly the same place as Cotumacci's San Onofrio.

In the late 1920 a young Karl Gustav Fellerer was working in the diocesan library in Münster, Germany. There he encountered the amazing collection of Fortunato Santini, the premier late eighteenth- and early nineteenth-century collector of musical manuscripts. As an orphan himself, tyro composer and churchman, Santini had collected dozens of manuscripts of partimenti from the great Catholic foundling homes conservatorii - of Naples. Fellerer, an organist, learned to play these manuscripts and became perhaps the first musicologist to recognize what they really represented. In more recent times Rosa Cafiero, Thomas Christensen and Giorgio Sanguinetti have gone much further in documenting and delineating this almost lost tradition. In my forthcoming Music in the Galant Style (New York: Oxford University Press, 2007), I attempt to show how the partimento tradition, and its companion tradition of Neapolitan solfeggi (graceful galant melodies paired with unfigured basses), were means for inculcating the schemata necessary to compose fluently. I present catalogues raisonnés of sixteen of the core schemata of the galant style, and in each case I show examples of how the schema was encoded in partimenti. The goal is to connect the musicological with the pedagogical, the product with the process, and in so doing to reveal the mental structures, the kind of intrinsically musical thoughts, that made this art possible. One could, of course, have learned to compose by other means, and clearly not every eighteenth-century composer studied in Italy with a partimento master. Still, the surviving records of partimento study are suggestive. Leading composers like J. S. Bach, Handel, Mozart and the Neapolitans, and the many famous students of Padre Martini in Bologna, all knew about partimenti. When one adds to their number the composers who studied with teachers trained in the Italian conservatories (for instance, Haydn with Porpora, or Dittersdorf with Bonno), one begins to see the outlines of an ingenious, widely disseminated, pre-industrial and non-verbal 'technology', an alchemical formula for transforming even foundlings into legendary composers.

Naples and Bologna were likewise two important centres for the training of actors in the tradition of improvised comedy known as commedia dell'arte. Apprentice actors needed to learn a large repertory of stock speeches, dialogues, scenes, comic 'business', stunts, jokes and playful banter, all written down to the extent possible in a manuscript zibaldone (commonplace-book). As the great comedian Barbieri put it ( $\mathrm{La}$ supplica, Venice, 1634), they had to 'study and fortify their memory with a wide variety of things such as sayings, phrases, love-speeches, reprimands, cries of despair and ravings, in order to have them ready for the proper occasion'. Much of the art of comedy lay in knowing how to judge the occasion and what to draw from that fortified memory. Pietro Maria Cecchini (Frutti delle moderne comedie et avisi a chi le recita, Padua, 1628) wrote of the mental discipline demanded by comedy: 'The actor must see to it that his mind controls his memory (which dispenses the treasure of memorized phrases over the vast field of opportunities constantly offered by comedy)'.

Burney's reverence for music from Italy - 'that part of the world, where it has been cultivated with such success; and from whence the rest of Europe has been furnished, not only with the most eminent composers and performers, but even with all its ideas of whatever is elegant and refined in that art' - led him to expect dignity, sobriety, even solemnity in Naples. The raucous commedia della musica that jarred his ears was a shocking disappointment. Yet if he had stayed longer than a few weeks, if he had taken lessons with Cotumacci, if he could have begun, through actual practice, to understand that a musical zibaldone (Galeazzi, Elementi teorico-pratici di musica, volume 2, Rome, 1796) of partimenti and solfeggi represented a 'treasure of memorized phrases' to be dispensed over the 'opportunities constantly offered' by music, he might finally have penetrated to one of the mysteries of Neapolitan success: the maestri taught an improvisatory tradition, a Divine Comedy of sound.

ROBERT O. GJERDINGEN

For the full text of Dr. Burney's journey see $<$ http://www.secm.org/texts.html>; for collections of partimenti see $<$ http://faculty-web.at.northwestern.edu/music/gjerdingen/partimenti/index.htm>. 